\title{
DUCHY MIEJSCA - NAPISY (GRAFFITI) W PRZESTRZENIACH PUBLICZNYCH I PRYWATNYCH JAKO PRZEDMIOT BADAŃ ARCHEOLOGII WSPÓŁCZESNEJ PRZESZŁOŚCI
}

SŁowa KLuCzowe: napisy, ryty, graffiti, archeologia niedawnej (współczesnej) przeszłości, pamięć

KEYWORDS: inscription, carvings, graffiti, archaeology of the recent past, memory

\section{WSTĘP}

Podpisywanie się w przestrzeni publicznej wydaje się jedną z bardziej powszechnych form manifestowania swojej obecności w świecie. Napisy w różnych miejscach publicznych pojawiają się już od czasów starożytnych i do dziś są bardzo często stosowaną praktyką społeczną. Jej motywacje są wielorakie: od prostego podpisania się w celu zaznaczenia obecności, poprzez deklarację sympatii bądź antypatii do jakiejś osoby, idei, aż po manifesty polityczne i zachęcanie do działania. Mimo popularności samego zjawiska i jego długotrwałości badanie napisów pojawiających się w różnych miejscach nie należy do tematów szeroko zgłębianych przez badaczy zajmujących się studiami nad niedawną przeszłością. Większość prac, które omawiają to zjawisko, ukazuje się w ramach kulturoznawstwa (por. Drozdowski 2007), socjologii (por. Osika 2008), czy studiów nad wizualnością (por. Pietkiewicz 2011). Niewiele natomiast skupia się na napisach jako świadectwach przeszłości mogących stanowić niezwykle cenne źródło do poznania mikrohistorii miejsc i ludzi. Interesującym wyjątkiem jest w tym względzie publikacja Adama Cyry Pozostał po nich ślad... (2006), w której to autor dzięki studiom nad napisami wyrytymi przez więźniów w przestrzeniach obozu koncentracyjnego Auschwitz-Birkenau zrekonstruował historie jednostek, które tam przebywały i napisał ich krótkie biografie. 
Artykuł ten skupia się na zaprezentowaniu wielu różnych kontekstów, w których pojawiają się graffiti. Jego celem jest także zaproponowanie potencjału badawczego napisów znajdujących się w przestrzeni publicznej dla badań nad niedawną i współczesną przeszłością (por. Olivier 2001). Za Laurentem Olivierem (2001) uważamy, że to odkrywanie przeszłości lokalnej jest cechą charakterystyczną archeologii współczesności. Naszym artykułem chcemy wskazać, jak istnienie grafitti w danej przestrzeni może pozwolić na odkrycie mikrohistorii ludzi i miejsca.

Napisy postrzegamy zgodnie z koncepcją Michaela Bella (1997) jako „duchy miejsca" (ghosts of place) uobecniające w danym miejscu tych, których już w nim nie ma. Ze względu na bardzo szeroki zakres badawczy, w ramach tego tekstu, zdecydowaliśmy się skupić głównie na grafitti łączących się z manifestacją czyjejś obecności w przestrzeni, zawężając nasze pole badawcze do takich, które opierają się głównie na formie pisemnej, a nie graficznej (rysunkowej). Nie koncentrujemy się na napisach o znaczeniu politycznym, lecz właśnie na tych, których głównym celem było wskazanie swojej obecności w danym miejscu. Dodatkowo, używając kilku studiów przypadku wskazujemy także na miejsca gdzie takie napisy mogą się pojawiać: zarówno w formie trwałej, jak i bardzo ulotnej (np. napisy na liściach).

W pierwszej części naszego artykułu omówimy znaczenie napisów jako źródłeł do badania przeszłości, a także ich potencjału dla pisania mikrohistorii i lokalnych wspomnień. Następnie przejdziemy do zagadnień związanych z pojawianiem się napisów w przestrzeniach publicznych i prywatnych. W ostatniej części artykułu skupimy się na koncepcji graffiti jako „duchów miejsca”.

\section{NAPISY W PRZESTRZENI PUBLICZNEJ JAKO ŹRÓDLO}

Wielu przedstawicieli nauk humanistycznych i społecznych (por. Bystroń 1980; Frederick 2009; Oliver, Neal 2010; Ouzman 2010; Ralph 2014) oraz osób spoza kręgów naukowych (regionalistów, dziennikarzy, reportażystów) zwróciło uwagę na to, że graffiti mogą stanowić cenne źródła do badania zarówno teraźniejszości, jak i niedawnej przeszłości. Wśród nich, naszym zdaniem, na szczególne wyróżnienie zasługuje Jan Stanisław Bystroń, który jako jeden z pierwszych zainteresował się tego typu wytworami z punktu widzenia źródła etnograficznego (Bystroń 1980). Przedmiotem jego badań były zarówno napisy ludowe (zdobiące domostwa, karczmy, dwory, kościoły i groby), jak i okolicznościowe (tworzone z okazji uroczystości i świąt) oraz sentencje wykonywane na różnego rodzaju przedmiotach użytkowych. Autor ten szczególną uwagę poświęcał motywacjom, jakie kierują osobami wykonującymi napisy i jednocześnie zauważał ich potencjał do dokumentowania zdarzeń chwilowych (Bystroń 1980: 109): 
Obok nich [szyldów, reklam, napisów informacyjnych - przypis autorów] są jednak i napisy żywe, pozostające w bliskim związku z człowiekiem, kładzione przezeń w chwili afektu, w nastroju podniosłym, podochoconym, namiętnym, napisy, które są życzeniem, zaklęciem, pamiątką, żartem, agitacją, paszkwilem. Im dalej się cofamy w przeszłość, tym więcej takich napisów; są one odwieczną literaturą, tradycyjnie przekazywaną w pokolenia. [...] są to drobne szczątki przeszłości, które mijamy w pośpiechu życia, fascynowani ogromem i świetnością dzisiejszych napisów wielkomiejskich.

J. Bystroń podkreśla zatem bliski związek napisów z człowiekiem. To, że opowiadają one o jednostkach zanurzonych w historyczności ówczesnego i współczesnego świata i stanowią źródło do badania nastrojów i wydarzeń chwilowych. Napisy są „,szczątkami przeszłości” i często jedynym świadectwem pewnych wydarzeń, czyjejś obecności i kryjących się za tym ludzkich historii.

J. Bystroń w swoich pracach analizował m.in. ryty pozostawiane na drzewach. Cytując dawną poezję wskazał, iż wykonywane były już od czasów starożytnych, a zwyczaj ten był często formą wyznawania miłości oraz zaznaczeniem swojej obecności podczas podróży (Bystroń 1980: 132-135).

Polski etnograf zwrócił uwagę, iż napisy tworzone przez turystów należą do najliczniejszych tego typu wytworów. Przywołał m.in. te wykonywane na egipskich piramidach, w schroniskach tatrzańskich i opuszczonych ruinach oraz zabytkach architektury (Bystroń 1980: 138-141). Cytował on także fragment wspomnień Henryka Sienkiewicza (2000: 59-60), który opisał swój pobyt nad wodospadem Niagara:

Ściany i balustrada wieżyczki pokryte są tysiącami napisów w języku angielskim, francuskim etc. Widziałem także napisy polskie i rosyjskie, każdy bowiem uważa sobie za obowiązek zostawić tu swoje nazwisko, również jak i datę odwiedzin. Co do mnie, jako dobry kolega, przekazałem wiekopomnej nieśmiertelności na ścianie nie tylko swoje nazwisko, ale i wszystkich znajomych, jakich na razie mogłem sobie przypomnieć, wszystkich kuzynek, kuzynów, a nawet i ich potomstwo. Młody Anglik obok swojego imienia Henry wypisał jeszcze imię Mary, po czym otoczywszy wszystko nader skomplikowanym zakrętasem oddalił się o kilka kroków przypatrując się z zadowoleniem swemu dziełu.

W opinii J. Bystronia próbą ochrony wielu podobnych miejsc stało się wystawianie ksiąg pamiątkowych. Miały one stanowić miejsce, w którym można zaznaczyć swoją obecność przy jednoczesnym braku niszczenia elewacji i wnętrz zabytków oraz innych elementów krajobrazu (Bystroń 1980: 140).

Nie tylko etnografowie i antropolodzy kulturowi poświęcają swoją uwagę graffiti jako źródłu do badania kultury. Napisy były wykorzystywane w bada- 
niach archeologicznych (Frąckowiak 2009; Frederick 2009; Oliver, Neal 2010; Ouzman 2010; Kobiałka i in. 2015). W Polsce studia Maksymiliana Frąckowiaka rozszerzone następnie przy współpracy z Dawidem Kobiałką i Kornelią Kajdą, poddały naukowej analizie napisy wyryte na powierzchni buków w pobliżu Chyciny, pow. międzyrzecki (por. Frąckowiak 2009; Kobiałka i in. 2015). Przedmiotem projektu było kilkadziesiąt rytów na drzewach znajdujących się wzdłuż transzei pochodzącej z okresu II wojny światowej (ryc. 1). Archeologiczne podejście do podpisów, opierające się na powiązaniu ich z kontekstem przestrzennym i historycznym, pomogło $\mathrm{w}$ ustaleniu, że wykonawcami napisów byli robotnicy przymusowi różnej narodowości (głównie Polacy i Rosjanie), których zmuszono do wykopania pobliskich fortyfikacji polowych w sierpniu $1944 \mathrm{r}$. Z kolei analiza pozostawionych dat pozwoliła na niezwykle dokładne określenie czasu wykonywanych prac (Frąckowiak 2009). Tylko dzięki podpisom więźniów udało się ustalić powyższe fakty i to właśnie graffiti stanowiło dla archeologów główne źródło odkrywania wiedzy o przeszłości badanego miejsca.

Warto zaznaczyć, iż na różnego rodzaju graffiti, traktowanych jako źródło do poznania historii danych osób i miejsc, bardzo często zwracają uwagę osoby niebędące reprezentantami świata nauki. Efekty ich dociekań i poszukiwań można odnaleźć w literaturze popularnonaukowej, bądź na internetowych forach dyskusyjnych. Takim odkrywcą był Ryszard Rowiński. Ten lubuski dziennikarz stworzył jeden ze swoich reportaży (Rowiński 1968) w oparciu o graffiti pozostawione we wnętrzach więzienia utworzonego w poaugustiańskim zespole klasztornym w Żaganiu. Odnalazł je na ścianach dawnych cel, na których napisy wykonywano zarówno ołówkiem, jak również wydrapywano w cegle lub tynku. Na podstawie podpisów autorowi udało się ustalić, iż w trakcie II wojny światowej przetrzymywano tam osoby z całej Europy m.in. z Polski, Niemiec, Francji, Włoch, Czechosłowacji, czy Hiszpanii. Analizując zachowane wówczas podpisy, daty, wiersze oraz ilustracje próbował odtworzyć epizody z życia więźniów (Rowiński 1968: 8-10).

Z kolei współczesną regionalistką i dziennikarką o zbliżonych do R. Rowińskiego zainteresowaniach jest Anna Straszyńska. Podobne przykłady badaczka ta odnalazła w piwnicach dwóch warszawskich obiektów - dawnego aresztu śledczego Głównego Zarządu Informacji Wojskowej przy ul. Świerszcza na Włochach (Straszyńska 2016) oraz podziemiach kamienicy przy ul. Strzeleckiej 8 na Pradze Północ, gdzie mieściła się główna kwatera dowództwa NKWD w Polsce (Straszyńska 2015). Oba te budynki stanowią miejsca pamięci związane $\mathrm{z}$ terrorem komunistycznym, a zachowane na nich podpisy są niekiedy jedynym źródłem dokumentującym obecność więzionych osób.

Graffiti stają się ponadto elementami wystaw muzealnych. Niektóre z nich eksponowane są in situ np. wewnątrz budynków obozowych i więziennych. 


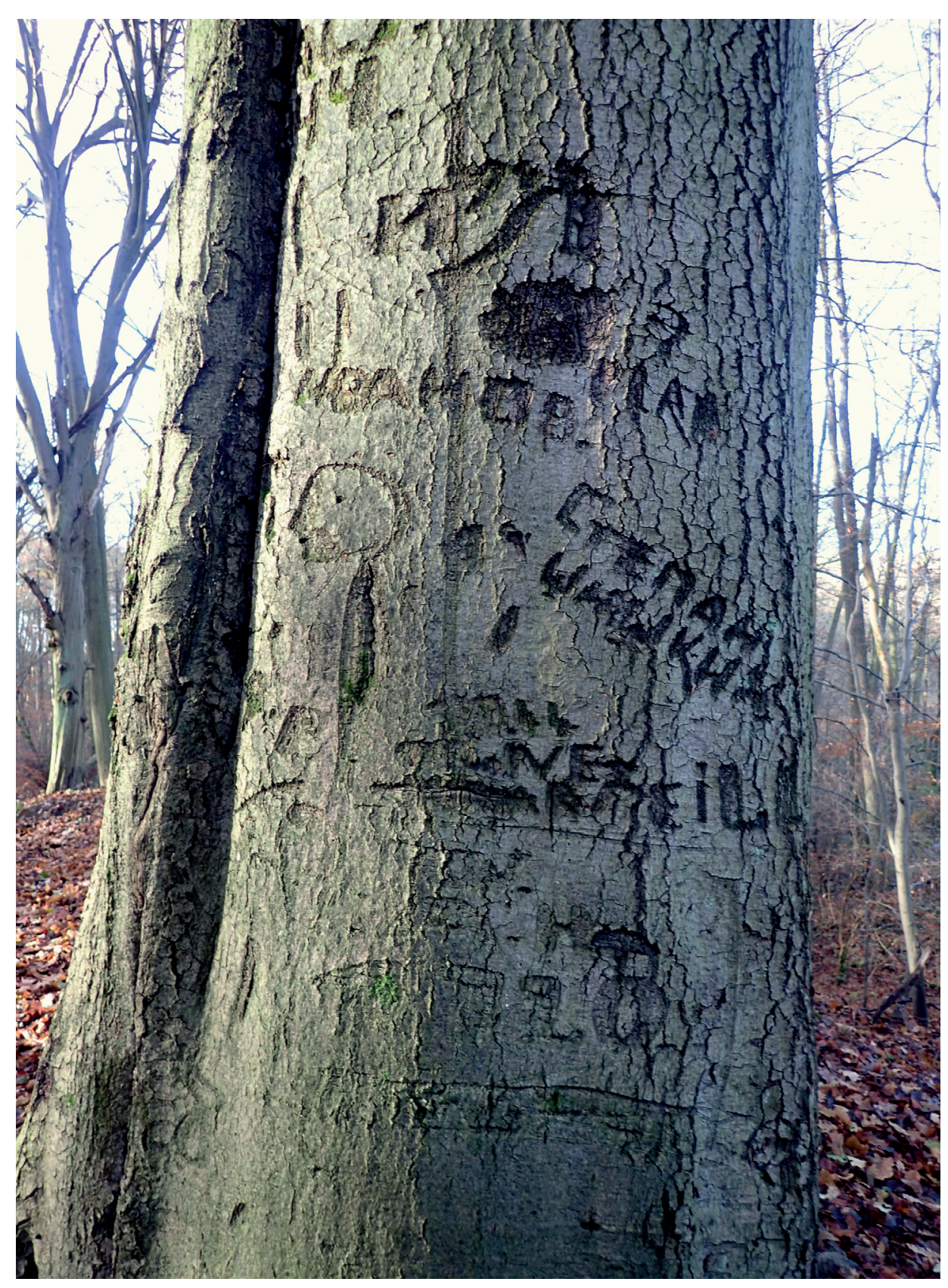

Ryc. 1. Chycina, pow. międzyrzecki. Napisy wykonane na bukach przez robotników przymusowych w sierpniu 1944 r. (fot. M. Frąckowiak). 
Przykładem tego rodzaju zabytków mogą być te zachowane na terenie Muzeum Martyrologii Wielkopolan mieszczącego się w Forcie VII w Poznaniu. Inne są wręcz przenoszone do muzealnych sal. Fragmenty murów z berlińskiego Reichstagu z pozostawionymi na nich podpisami radzieckich żołnierzy podziwiać można w Centralnym Muzeum Sił Zbrojnych w Moskwie. Z kolei fotografia, której autorem jest Anatoly Morozov, przedstawiająca czerwonoarmistę podpisującego się 9 maja 1945 r. na usłanej graffiti i śladami po pociskach ścianie tego gmachu, stanowi jedno z najbardziej znanych zdjęć ze zbiorów Moskiewskiego Domu Fotografii przekształconego w 2016 r. w Multimedialny Zespół Sztuki Aktualnej (Rybchinsky 2006: 117).

\section{WSZECHOBECNOŚĆ I TRWALOŚĆ NAPISÓW}

Pojawianie się grafitti jest charakterystyczne dla różnych przestrzeni. Można je odnaleźć właściwie wszędzie. Udało się nam je zaobserwować na elewacjach i we wnętrzach budynków, w tym zabytków. Wśród nich są przenikające się

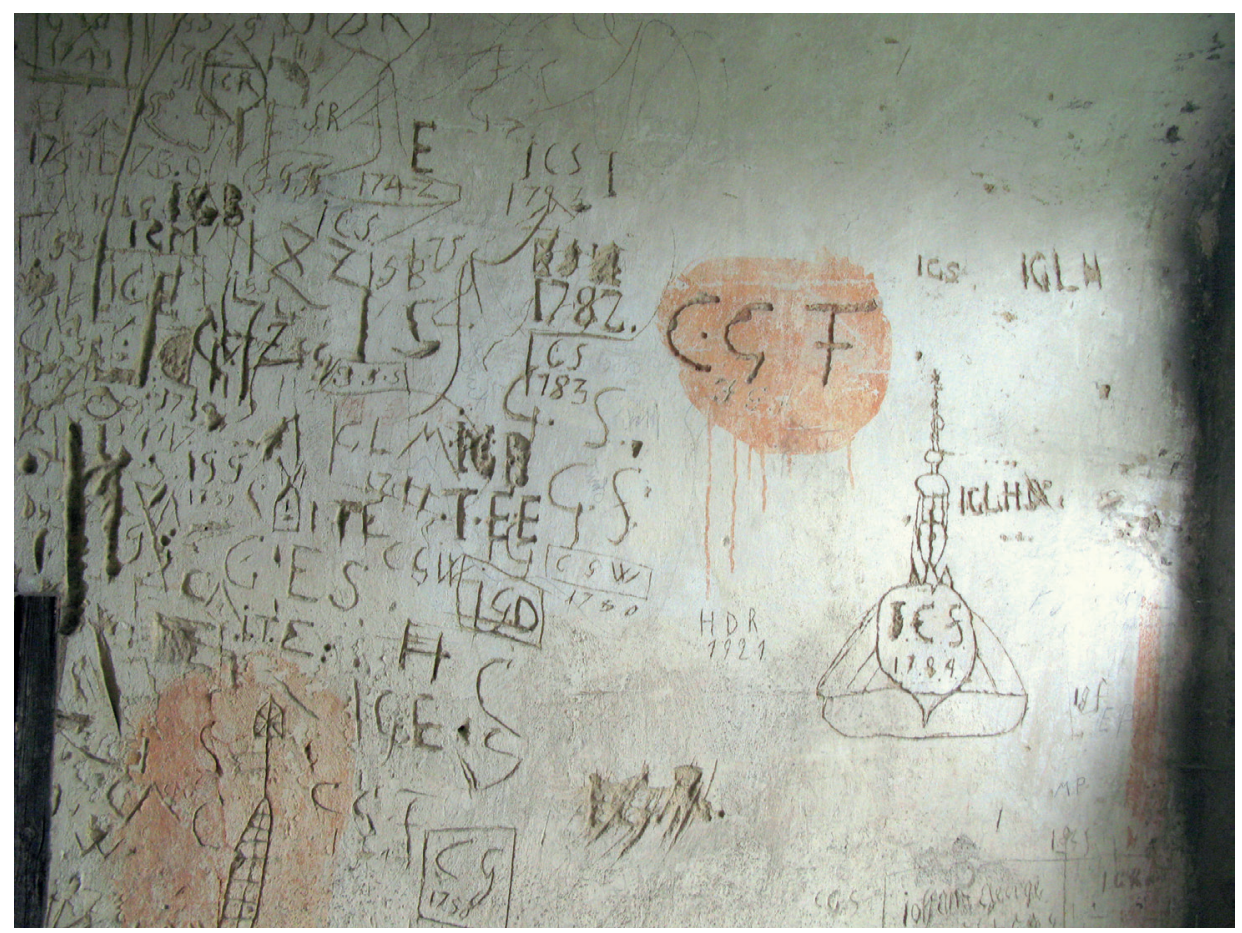

Ryc. 2. Niedów, pow. zgorzelecki. Graffiti pozostawione we wnętrzu wieży kościoła p.w. Matki Boskiej Anielskiej (fot. M. Frąckowiak). 
napisy wyryte na wieży kościoła p.w. Matki Boskiej Anielskiej w Niedowie, pow. zgorzelecki, gdzie grafitti wykonywano od początku XVIII w. aż po czasy współczesne (ryc. 2).

Kolejnym przykładem jest Rotunda w Zamościu - dawny fort, w którym w czasie II wojny światowej Niemcy ulokowali obóz koncentracyjny głównie dla ludności z terenów Lubelszczyzny. Na ceglanych murach cel znajdują się setki napisów pozostawionych przez więźniów (ryc. 3). Z kolei na terenie pomieszczeń socjalnych koszar w Jüterbogu (Neues Lager) we wschodnich Niemczech zadokumentowaliśmy liczne podpisy żołnierzy armii radzieckiej i armii rosyjskiej stacjonujących do 1993 r. na obszarze NRD (ryc. 4).

Badając napisy musimy mieć świadomość ich nietrwałości. Są to źródła, które mogą zostać w każdej chwili zamazane lub zniszczone. Zależne jest to zarówno od materiału, na którym zostały wykonane, jak również od działalności człowieka (np. remonty, rozbiórki, wycinka drzew, brak ochrony konserwatorskiej).

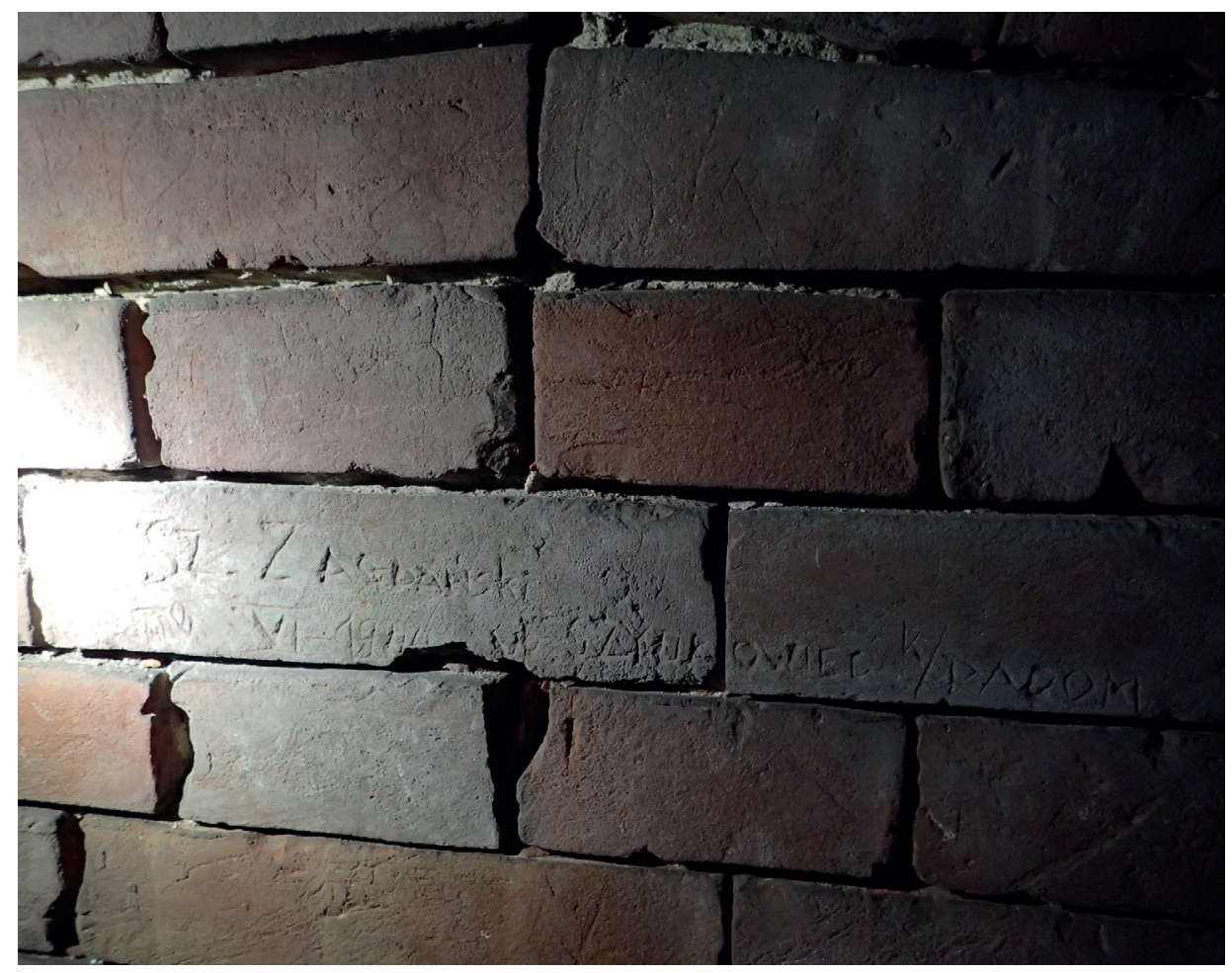

Ryc. 3. Zamość. Napisy we wnętrzach cel Rotundy - byłego obozu koncentracyjnego (fot. M. Frąckowiak). 


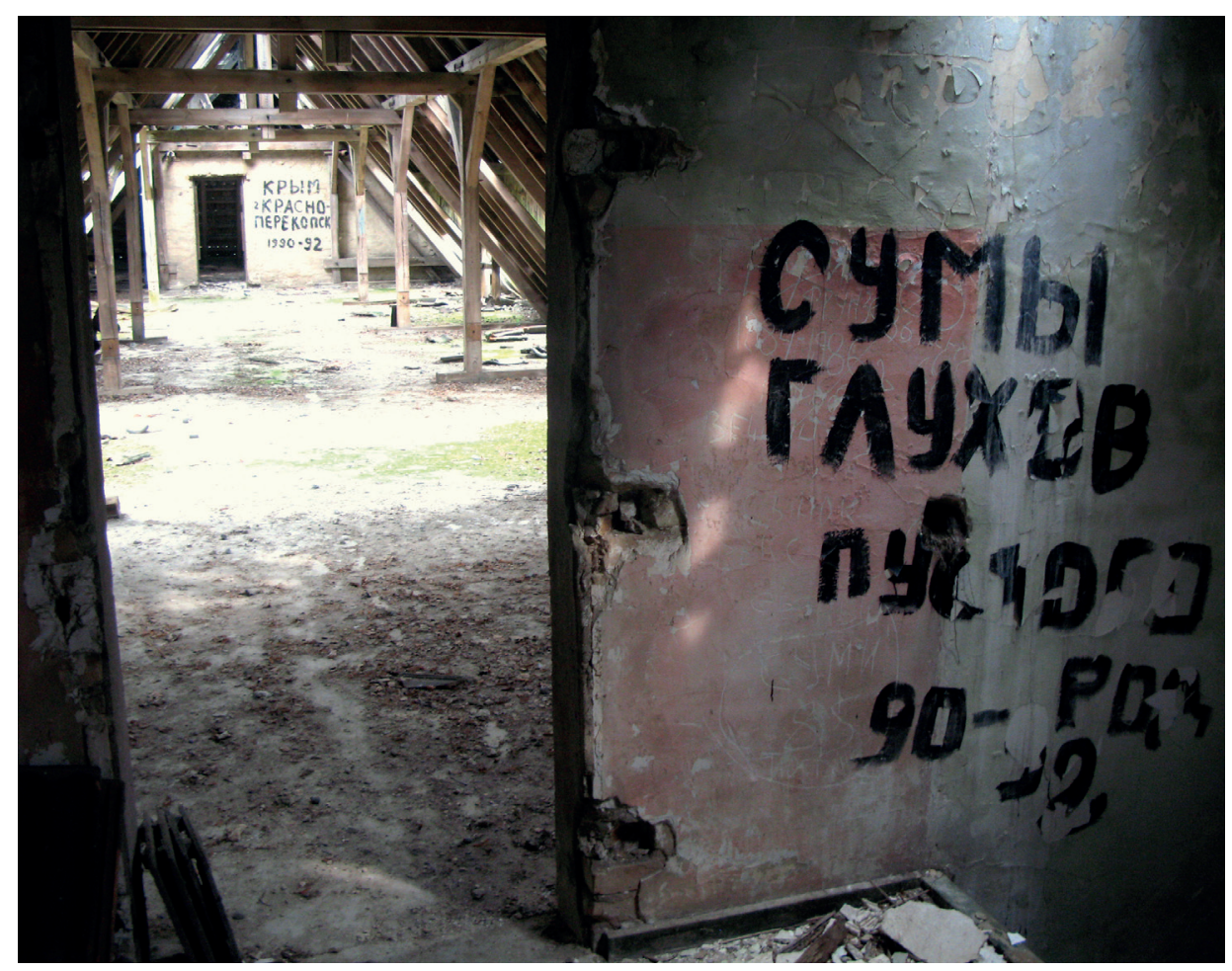

Ryc. 4. Jüterbog (Niemcy). Podpisy żołnierzy rosyjskich w budynkach dawnych koszar wojskowych (Neues Lager) (fot. M. Frąckowiak).

Jak już wspominaliśmy, podłożem dla graffiti są nie tylko ściany budynków. Mogą nim być także substancje znacznie mniej trwałe, często elementy przyrody żywej i nieożywionej (Oliver, Neal 2010). Takie praktyki w Polsce opisał przywoływany już J. Bystroń nazywając zabawę dziecięcą polegającą na wykonywaniu napisów na młodych dyniach „figlami ogrodniczymi”, które utrwalają się wraz ze wzrostem rośliny (Bystroń 1980: 158). Wytrzymałość takich znaków zależy od wielu czynników - w przypadku roślin będą to m.in długość życia oraz różne procesy wegetacyjne. Nieco dłużej przetrwają, zatem napisy wyryte na powierzchni kaktusów zaobserwowanych przez nas w Rabacie w Maroko (ryc. 5), a znacznie krócej te wykonane na długich liściach różnych gatunków roślin na terenie Phnom Pen w Kambodży (ryc. 6).

Na niektórych roślinach graffiti mogą pozostać jednak znacznie dłużej. Jako przykład posłużyć mogą wspomniane napisy na korze buków rosnących nieopodal Chyciny, pow. międzyrzecki, z których najstarsze mają już ponad 100 lat. Podobne obiekty można w Polsce zaobserwować także na innych gatunkach drzew. 


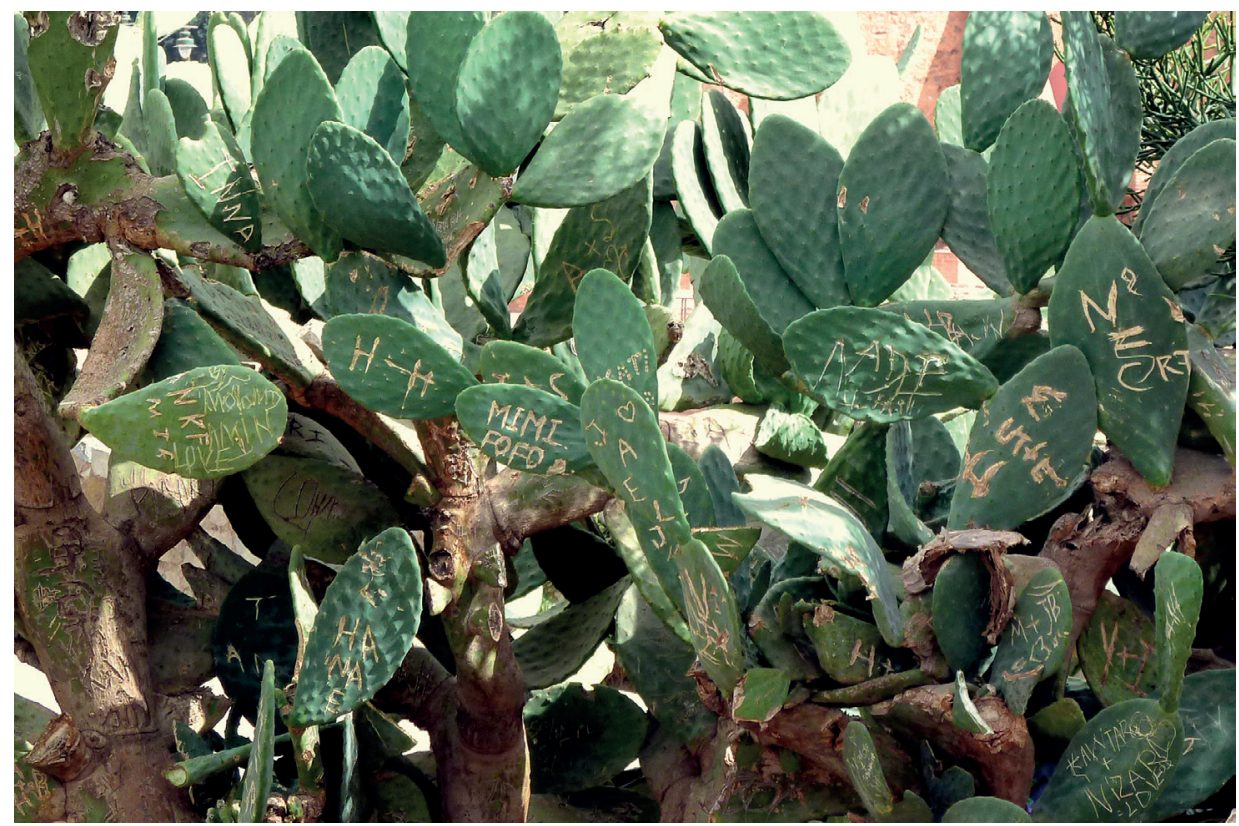

Ryc. 5. Rabat (Maroko). Napisy wykonane w miejskim parku na powierzchni kaktusów (fot. K. Kajda).

Zwłaszcza tych o względnie gładkiej korze, jak np. wiąz lub jesion. Szczególnie dużo jest ich w parkach, przy szkołach lub jednostkach wojskowych (por. Merril, Hack 2013). W pobliżu budynków dawnych koszar w Żarach wielu żołnierzy wyryło w korze swoje imiona, nazwy miejscowości, z których pochodzili, czy też jednostek oraz daty odbycia służby wojskowej (ryc. 7). Różną żywotnością charakteryzują się także graffiti wykonane na powierzchni skał. Uzależniona jest ona od szeregu procesów niszczących, np. wietrzenia lub osuwania. Te wyryte głęboko w kamiennych ścianach mogą przetrwać tysiące lat, natomiast inne zaledwie kilka tygodni bądź miesięcy. Do drugiej grupy zaliczyć można podpisy turystów pozostawione na lessowych skarpach wąwozu korzeniowego w Kazimierzu Dolnym, pow. puławski (ryc. 8).

Wszechobecność graffiti sprawia, że często wydają się tak oczywiste, że aż nieistotne. Jak pisał J. Bystroń (1980) na co dzień nie zwracamy już nawet uwagi na te znajdujące się wokół nas. Jest ich bowiem zbyt dużo i stały się one wręcz „naturalnym” towarzyszem przestrzeni, w których się obracamy. Właśnie ta codzienność i zwyczajność napisów oraz świadomość tego, że mogą w każdej chwili być nadpisane czymś nowym sprawia, że w procesie badawczym związanym z konkretnym miejscem są one nierzadko pomijane. 


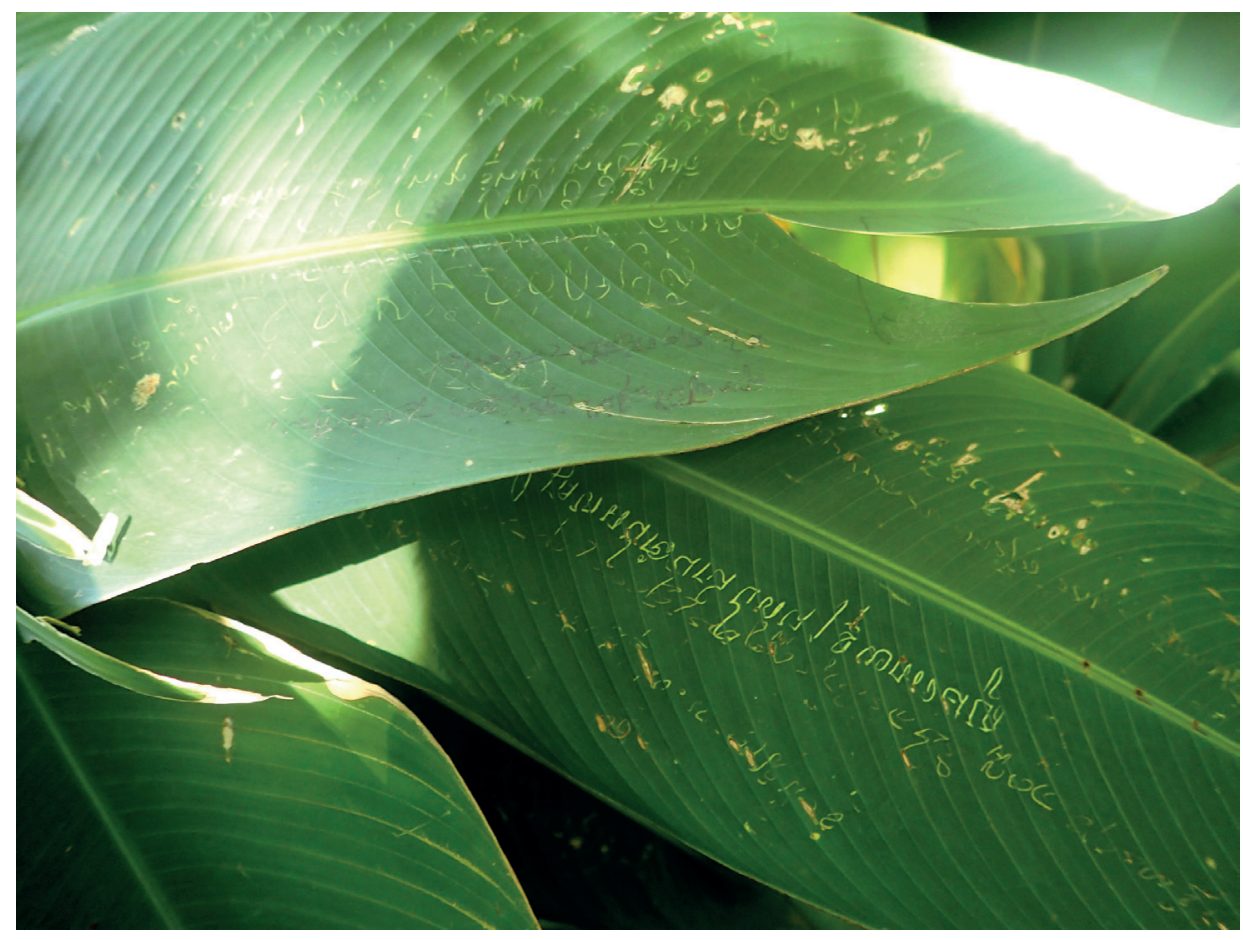

Ryc. 6. Phnom Pen (Kambodża). Graffiti pozostawione w parku na powierzchni roślin ozdobnych (fot. K. Kajda).

$\mathrm{Na}$ napisy nie zwraca się uwagi, ponieważ nie ma pewności co do daty ich stworzenia, zdarza się także, że są przysłonięte kolejnymi warstwami tekstu. Pomimo tego to właśnie one niejednokrotnie stanowią jedyne pozostałości po działalności konkretnych osób w określonym miejscu. Imię i nazwisko z datą świadczą o jednostkach, które przebywały w danej przestrzeni, co może mieć duży wpływ na interpretację jej znaczenia. Kultura materialna w postaci przedmiotów może ulec zatarciu, zostać przysłonięta grubymi połaciami ziemi, zniszczona lub po prostu zabrana. W przypadku napisów jest często inaczej. One pozostają na drzewie wokół transzei, na murach obozów koncentracyjnych i więzień, czy też na liściach okolicznych krzewów. Napisy mimo swej powszechnej obecności dalej zaświadczają o momentach w historii, epizodach pojawiania się kogoś w danej przestrzeni, lub o jego długotrwałym pobycie (por. Kobiałka i in. 2015). To właśnie jest, naszym zdaniem, ich jeszcze niewykorzystany archeologicznie potencjał, zwłaszcza w kontekście archeologii współczesnej i niedawnej przeszłości. 


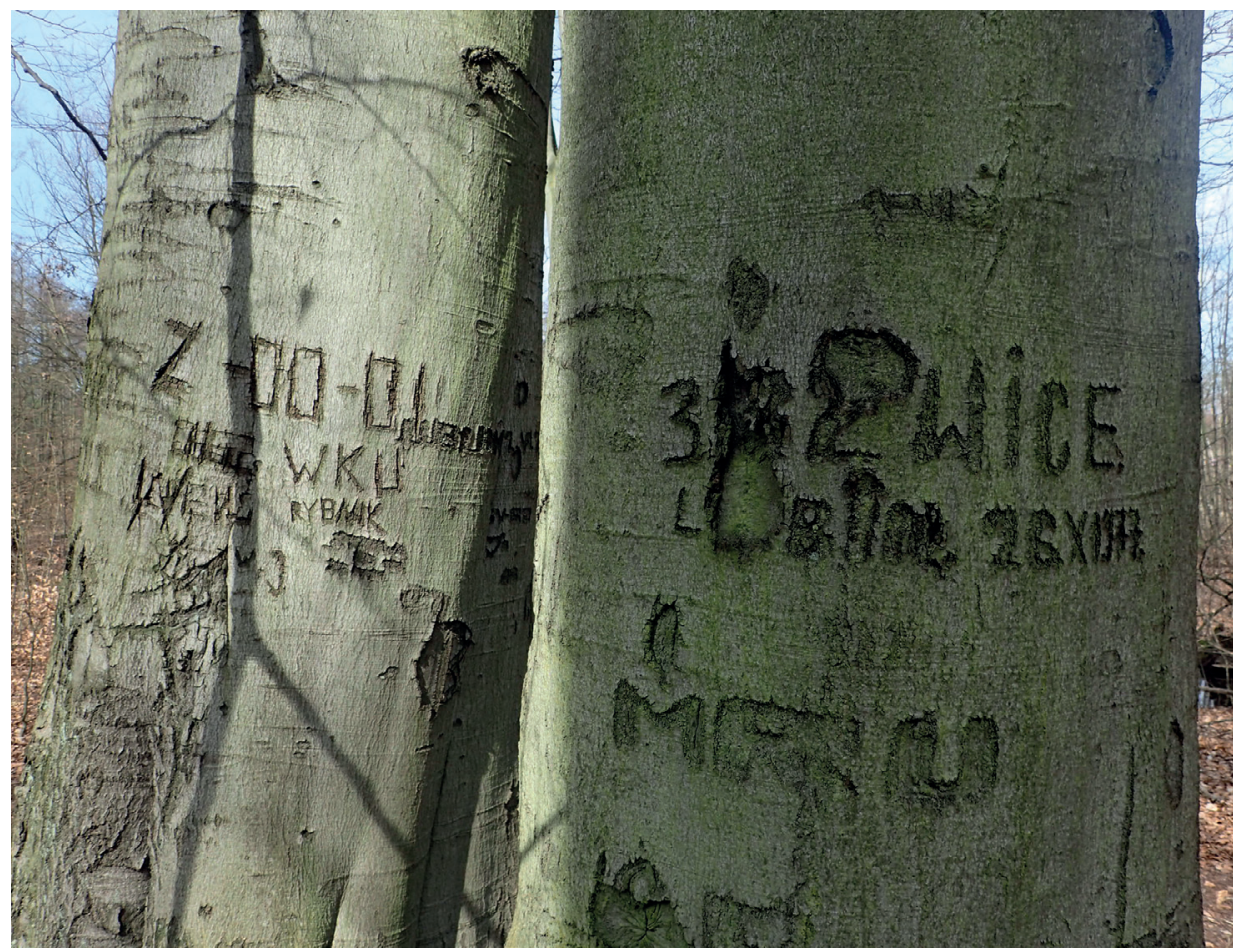

Ryc. 7. Żary. Podpisy polskich żołnierzy na powierzchni drzew w pobliżu dawnych koszar wojskowych (fot. K. Kajda).

\section{NAPISY JAKO ŚWIADECTWA MIKROHISTORII}

Potencjał, który widzimy w napisach w ramach archeologii współczesnej czy niedawnej przeszłości wynika z faktu, że dziedzina ta ma wyjątkową możliwość dokładnego studiowania wydarzeń w skali mikro - tych związanych z historiami zwykłych ludzi i ich obecnością w świecie. Zdaniem L. Oliviera (2001) to właśnie skupienie się na mikrohistoriach i działanie w ramach „archeologii krótkiego czasu” świadczy o szczególnym znaczeniu tej gałęzi nauki. Wspomniany badacz twierdzi nawet więcej, według niego jest to jedyna właściwa metoda uprawiania archeologii współczesnej przeszłości (Olivier 2001: 179):

Tracimy pewien dystans w momencie, w którym wyobrażamy sobie, że archeologia współczesności bada przeszłość w taki sam sposób jak archeologia czasów bardziej odległych. Pozostałości po niedalekiej przeszłości niosą tyle samo archeologicznej wiedzy, co te pochodzące z czasów starożytnych. Lecz, jeśli jeszcze nie jesteśmy w stanie 
pojąć samego środka przekazu i długotrwałej dynamiki, do której dane pozostałości były przypisane, to nie jesteśmy w stanie także przyswoić tej wiedzy. W takim sensie zasadne jest postulowanie by powstała autonomiczna dziedzina: archeologia współczesnej przeszłości. Błędem byłoby wtłaczanie takiej archeologii pomiędzy te bardziej tradycyjne podejścia. [W przypadku archeologii współczesności - przypis autorów] Powinniśmy skupiać się na archeologii krótkiego czasu. Takie podejście, z jednej strony, bierze pod uwagę specyficzne dochodzenie związane z niedaleką przeszłością, lecz z drugiej strony powinno rozwinąć problematykę dotyczącą historycznej dynamiki i skali krótkiego czasu (rozciągającą się od kilku godzin do kilku generacji wstecz).

Zatem archeologia współczesnej przeszłości powinna skupiać się na wydarzeniach krótkotrwałych oraz świadectwach jedynie chwilowych działań, gdyż tylko te, zdaniem L. Oliviera, możemy objąć swoją wiedzą i namysłem w szerszym kontekście społeczno-historycznym. Być może dopiero za kilkaset lat badacze kultury będą w stanie złożyć w całość nasze dzisiejsze rozważania na temat epizodów współczesnej przeszłości i zinterpretować je w szerokim kontekście. Dlatego dziś, jako archeolodzy niedawnej przeszłości,

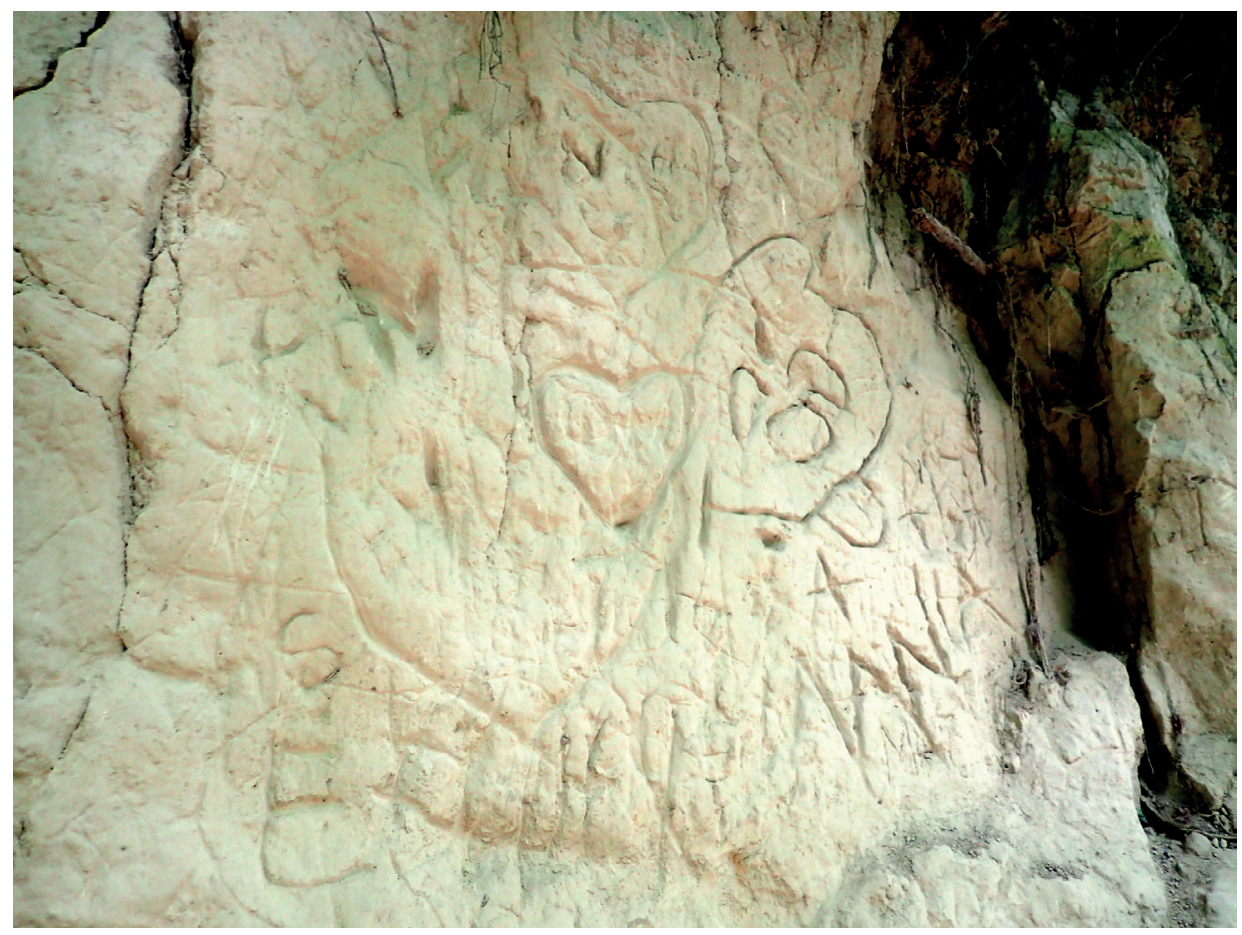

Ryc. 8. Kazimierz Dolny, pow. puławski. Podpisy turystów pozostawione na lessowej skarpie wąwozu korzeniowego (fot. K. Kajda). 
powinniśmy skupiać się na tym co lokalne i krótkotrwałe, by i to nie minęło zapomniane. W takim sensie, można nawet stwierdzić, że aktualnie analizując niedawną przeszłość tworzymy podwaliny dla przyszłych studiów nad naszym społeczeństwem.

Taką możliwość analizowania historii krótkiego zasięgu dają właśnie omawiane przez nas napisy. To w nich zastyga moment związany z przebywaniem kogoś w danym miejscu (czasem jedynie chwilowym, innym razem godzinnym, kilkumiesięcznym, czy kilkuletnim), i to one dają możliwość badania historii w skali mikro. To także napisy są źródłami, jak już wspominaliśmy, bardzo krótkotrwałymi i już za kilka lat, czy nawet miesięcy ich potencjał może być nie do wykorzystania.

W tym artykule chcemy wskazać, że zwykłe, napotykane codziennie napisy na murach czy drzewach mogą przyczyniać się do odkrywania właśnie tych epizodycznych wydarzeń - zbliżających nas do życia codziennego i do „zwykłego człowieka”. Założenia L. Oliviera (2001) dla archeologii współczesnej przeszłości chcielibyśmy poszerzyć jeszcze o kontekst odkrywania historii „Zwykłego człowieka", który był już wspominany także przez J. Bystronia (1980). Kierujemy się tutaj słowami białoruskiej noblistki Swietłany Aleksijewicz, która to w słynnym reportażu Cynkowi chtopcy napisała (2015: 23-24):

Co się dzieje z wielkimi wydarzeniami? Przenoszą się do historii. A te małe, dla małego człowieka jednak najważniejsze, znikają bez śladu. [...] W każdej kolejnej książce z uporem robię to samo - zmniejszam historię do rozmiarów człowieka.

Ze względu na to, że napisy „pozostają w bliskim związku z człowiekiem” (Bystroń 1980) pozwalają archeologom zajmującym się współczesną przeszłością na „zmniejszanie historii do rozmiarów człowieka”. Krótkie wspomnienia na murach czy drzewach są dla nas źródłem do badania przeszłości o rozmiarze jednostek. Owe intencjonalne znaki są opowieścią na temat indywidualnych losów i jednocześnie próbą zaznaczenia swojej obecności w tej wielkiej historii świata i ogromnej przestrzeni, którą zamieszkujemy. Często są one jedynymi poświadczeniami o pewnych epizodach z przeszłości. Dodatkowo, ich niezwykła wartość wynika z tego, że dają możliwość zidentyfikowania głównego bohatera wydarzenia poprzez jego podpis. Wszystko to sprawia, że tak istotne jest postrzeganie napisów jako źródeł do badania przeszłości, tym bardziej, że mogą one niedługo zupełnie zniknąć za nowymi warstwami farby.

Interesującym przykładem dokumentowania za pomocą napisów epizodów z przeszłości dotyczących życia zwykłego człowieka jest historia opisywana przez Leonarda Rosadzińskiego (2014). Pod koniec lat 90. w piwnicy przy ul. Skrytej w Poznaniu prowadzono prace remontowe. Po odsunięciu starego 
regału na suficie ujawniono napis wykonany dymem ze świeczki „Tutaj Byłem Maryś Orłowski”. Okazało się, że w 1940 r. właściciele piwnicy (Państwo Szymańscy) przez dwa dni ukrywali w niej żydowską rodzinę. Jeden z jej członków postanowił to wydarzenie utrwalić (upamiętnić) za pomocą podpisu. Gdyby nie zaznaczenie swojej obecności przez Marysia, historia ukrywania w piwnicy osób pochodzenia żydowskiego, mogła funkcjonować jedynie jako opowieść rodzinna, znana zaledwie kilku osobom. Właśnie to znalezisko pozwoliło na przypomnienie i opisanie dwudniowego wojennego epizodu, który miał miejsce na poznańskim Łazarzu. Odnaleziony napis stanowił jedyne źródło materialne pozostałe po tym wydarzeniu (Rosadziński 2014: 36), i właśnie chęć zaznaczenia swojej obecności oraz dociekliwość badawcza pozwoliły kolejny raz na umieszczenie jednostki w szerokich ramach historii II wojny światowej.

Dodatkowo, odkrywanie napisów, dochodzenie do ich chronologii poprzez „ściąganie” z nich pewnych warstw jest samo w sobie niezwykle ,archeologiczne". Tu, podobnie jak w tzw. archeologii terenowej, spośród licznego materiału przykrywającego interesujące warstwy, musimy wybrać to, co wydaje się istotne dla naszej pracy i to, co jest już na danym etapie badawczym mniej ważne. Następnie owe dane musimy odczytać i zinterpretować w szerszym kontekście geograficznym, historycznym i społecznym. Dopiero wówczas napisy stają się dla nas ważnym i interesującym źródłem. Już jeden napis (podobnie jak jeden fragment ceramiki znaleziony na polu) może być inspiracją do spojrzenia na przeszłość miejsca w inny sposób i do natknięcia się na dotąd nieznane lub zapomniane epizody. Stało się tak w przypadku buków z okolic Chyciny, gdzie to właśnie uważne przyglądanie się przestrzeni i krajobrazowi oraz ciekawość badawcza najpierw jednej, a potem kilku osób, przyczyniły się do poznania historii robotników przymusowych z okresu II wojny światowej (por. Frąckowiak 2009; Kobiałka i in. 2015). Podobnie rozwinęla się historia z ul. Skrytej w Poznaniu, gdzie odsunięcie szafy i potraktowanie napisu jako przyczynku do dalszych badań, pozwoliło na napisanie nowej historii zwykłej piwnicy. Właśnie owo potraktowanie napisów jako źródeł pozwala na nadanie im zupełnie nowego znaczenia oraz docenienie ich wartości dla studiów nad przeszłością.

\section{DOŚWIADCZAJĄC PRZESTRZENI - NAPISY JAKO „DUCHY MIEJSCA”}

Jak wynika z powyższych akapitów, podpisywanie się w różnych przestrzeniach jest praktyką społeczną odbywającą się od czasów starożytnych aż do dziś (por. Baird, Taylor 2010; Oliver, Neal 2010; Graves-Brown, Schofield 2011). Nie pozostaje ona bez wpływu na otaczający świat i przestrzeń, w której umieszcza się graffiti. Pojawianie się napisów w różnych miejscach zmienia sposób ich postrzegania. Piwnica z ul. Skrytej w Poznaniu po odnalezieniu w niej podpisu Marysia Orłowskiego nie będzie tak samo widziana przez jej 
właścicieli, jak przed odkryciem graffiti. Podobnie, podpisy więźniów w Rotundzie w Zamościu sprawiają, że zwiedzając to miejsce odczuwa się wręcz bliskość tych, którzy byli tam przetrzymywani. Interesującą interpretację tego, jaki wpływ na miejsce mają pozostawiane w nich ślady w postaci napisów zaproponował Michael Bell. Badacz ów ten sposób „doświadczania” przestrzeni opisał jako „duchy miejsca” (ghosts of place), które definiuje jako: „odczuwanie obecności [w danym miejscu - przypis autorów] tych, których nie ma fizycznie" (Bell 1997: 813). Według M. Bella (1997: 813):

[...] duchy pomagają w stworzeniu pewnej specyficzności stanowisk historycznych, miejsc, do których czujemy przynależność i zarazem nie przynależymy [...]. Duchy zarówno żywych jak i martwych, tych pojedynczych jak i grupowych dusz, innych i nas samych, nawiedzają miejsca naszego życia.

Zgodnie z jego koncepcją (1997) napisy są śladem stwarzającym wrażenie obecności osoby, która je stworzyła kilka lub nawet kilkaset lat temu. Sprawia to, że grafitti mimo że napotykane współcześnie, są wieloczasowe i wielokontekstowe. Będąc odkrywane w teraźniejszości bardzo mocno odsyłają nas do przeszłości.

W przypadku napisów, inaczej niż z fragmentami ceramiki, czy też szpilami z epoki brązu, odczuwamy bezpośredni związek z samym twórcą - człowiekiem, który świadomie zasygnalizował swoją obecność w danym miejscu. Widząc imię i datę wyrytą na ścianie lub drzewie możemy wyobrażać sobie, kim była dana osoba i dlaczego postanowiła się podpisać. Motywacje twórców mogą bowiem mieć wieloraki charakter. Od błahej, bezrefleksyjnej chęci wykonania podpisu, jak np. ryty w Wąwozie Korzeniowym w Kazimierzu Dolnym, po pozostawienie informacji naznaczonej pewnym ładunkiem emocjonalnym, będącej wręcz wołaniem o zauważenie jej w przyszłości. Do tej drugiej grupy zaliczyć można wszelkie graffiti wykonywane w warunkach zagrożenia życia, zwłaszcza na terenach więzień i obozów koncentracyjnych. W tym wypadku istotny jest także kontekst historyczny, w którym pojawiają się napisy. To dzięki znajomości przeszłości miejsca jeszcze silniej odczuwamy „nawiedzanie” nas przez intencjonalne znaki. Jak ujmuje to J. Bystroń (1980) napisy są ciągle ,żywe” i pozostają w bliskim związku z człowiekiem. Owo połączenie graffiti z jednostką jest niezwykle istotne w koncepcji M. Bella (1997), bo to ono właśnie pozwala na „uobecnianie” tych, których $\mathrm{w}$ danym miejscu już nie ma.

„Nawiedzanie” i odczuwanie obecności innych jest wszechobecne. Będąc właściwie w każdym miejscu możemy poczuć, że nie byliśmy tam pierwsi, że ktoś już je odwiedził i niejednokrotnie zaznaczył swoją obecność poprzez 
podpis, wyrycie znaku, czy choćby porzucenie po sobie jakichś pozostałości. Zdaniem M. Bella (1997) to właśnie dzięki takim stałym poświadczeniom obecności miejsca są „uosobione”. Oznacza to, że napisy, podpisy pomimo bezpośredniego braku ich twórców nadal trwają i zaświadczają o ich przebywaniu. Sprawia to, że pusta przestrzeń jest zawsze wypełniona czyjąś obecnością - „uosobiona”, by użyć słów M. Bella. Miejsca zatem, stają się pełne znaczeń i śladów tych, którzy postanowili zaznaczyć tam siebie i właśnie przez to odczytywanie i doświadczanie owych przestrzeni zawsze odsyła nas do przeszłości i wydarzeń, które mogły się w nich dziać.

\title{
Podsumowanie
}

Archeologia współczesnej przeszłości posługując się specyficznymi źródłami i opisując bliskie zdarzenia powinna, zdaniem L. Oliviera (2001), zwracać się w kierunku opisywania mikrohistorii, które w przyszłości pomogą w tworzeniu spójnej opowieści na temat czasów najnowszych. Jednym ze sposobów opowiadania o owych krótkotrwałych wydarzeniach jest badanie napisów pojawiających się w różnych przestrzeniach. Zaznaczanie swojej obecności w postaci podpisu jest popularną praktyką społeczną stosowaną od czasów najdawniejszych aż po dzień dzisiejszy, traktowaną zazwyczaj jako akt wandalizmu na elementach architektury i przyrody. Napisy pojawiające się w różnych miejscach mogą jednak być odczytywane jako „duchy miejsca”, zaświadczające o obecności osób już w nich niebędących. Są one istotną częścią krajobrazu i nadają mu nowe znaczenia. Jak wykazaliśmy w artykule, potencjał owych graffiti dla archeologii, zwłaszcza tej koncentrującej się na współczesnej przeszłości, jest bardzo duży. W wielu wypadkach stanowią one jedyne źródło wiedzy o czyimś pobycie w określonym miejscu i wydarzeniach odbywających się $\mathrm{w}$ danej przestrzeni. To napisy, mogą nadać niezwykle istotny społeczny kontekst badaniom archeologicznym. To właśnie dzięki graffiti jesteśmy w stanie uchwycić historię krótkotrwałą, incydenty z życia zwykłych ludzi - często niemożliwe do zaobserwowania przez badaczy przeszłości za pośrednictwem „tradycyjnych” artefaktów. Zatem również my - archeolodzy - możemy, zwracając uwagę na szereg źródeł znajdujących się dookoła nas, nie tylko pod ziemią, ale także na niej, pisać mikrohistorie miejsc, krajobrazów i ludzi.

\author{
Kornelia Kajda \\ Instytut Archeologii \\ Uniwersytet im. Adama Mickiewicza w Poznaniu \\ ul. Umultowska 89D \\ 61-614 Poznań \\ e-mail: kornelia.kajda@gmail.com
}


Maksymilian Frąckowiak

Pracownia Badań Historycznych i Archeologicznych „Pomost”

ul. Kłuszyńska 20/26

60-136 Poznań

e-mail: maksymilian.frackowiak@gmail.com

\section{Bibliografia}

Aleksijewicz S. (2015), Cynkowi chłopcy, Czarne, Wołowiec.

Baird J.A., Taylor C. (red.) (2010), Ancient graffiti in context, Routledge, London.

Bell M. (1997), The Ghosts of Place, „Theory and Society”, t. 26, s. 813-836.

Bystroń J. (1980), Tematy, które mi odradzano. Pisma etnograficzne rozproszone, oprac. L. Stomma, PIW, Warszawa.

Cyra A. (2006), Pozostał po nich ślad..., Państwowe Muzeum Auschwitz-Birkenau, Oświęcim.

Drozdowski R. (2007), Obraza na obrazy. Strategie spolecznego oporu wobec obrazów dominujących, Zysk i S-ka, Poznań.

Frąckowiak M. (2009), Historia na drzewach zapisana. Przyczynek do poznania dziejów MRU na podstawie napisów zachowanych na bukach $w$ poblizu Chyciny, [w:] B. Mykietów, M. Tureczek (red.), Ziemia Międzyrzecka w przeszłości, t. 7, Muzeum w Międzyrzeczu, Międzyrzecz, s. 143-150.

Frederick U.K. (2009), Revolution is the new black: graffiti/art and mark-making practices, „Archaeologies”, t. 5(2), s. 210-227.

Graves-Brown P., Schofield J. (2011), The filth and the fury: 6 Denmark Street (London) and the Sex Pistols, „Antiquity”, t. 85(330), s. 1385-1401.

Kobiałka D., Frąckowiak M., Kajda K. (2015), Tree memories of the Second World War: a case study of common beeches from Chycina, Poland, „Antiquity”, t. 89(345), s. $683-696$.

Merril S.O.C., Hack H. (2013), Exploring hidden narratives: conscript graffiti at the former military base 'Kummersdorf', „Journal of Social Archaeology”, t. 13(1), s. 101-21.

Olivier L. (2001), The archaeology of the contemporary past, [w:] V. Buchli, G. Lucas (red.), Archaeologies of the contemporary past, Routledge, London, s. 175-188.

Oliver J., Neal T. (2010), Elbow grease and time to spare: the place of tree carving, [w:] J. Oliver, T. Neal (red.), Wild Signs: Graffiti in Archaeology and History (= BAR International Series), Oxford, s. 15-22.

Osika G. (2008), Grafitti-znaki miasta, „Zeszyty Naukowe Politechniki Śląskiej” t. 43, s. $125-146$.

Ouzman S. (2010), Graffiti as art(e)fact: a contemporary archaeology. Wyktad wygtoszony podczas University of Johannesburg Sociology, Anthropology and Development Seminar, Johannesburg, 10 marca 2010, https://www.uj.ac.za/faculties/ humanities/sociology/Seminars/2010/Ouzman\%202010\%20Graffiti.pdf (dostęp: 4.11.2016). 
Pietkiewicz A. (2011), Street art - komunikacja masowego rażenia. Szkice o graffiti, stencilach i stickerach, „Ikonosfera. Studia z socjologii i antropologii obrazu”, t. 3, s. 63, http://www.ikonosfera.umk.pl/fileadmin/pliki/Ikonosfera_3_Aleksander_Pietkiewicz_Street_art.pdf(dostęp: 10.11.2016).

Ralph J. (2014), Graffiti Archaeology, [w:] C. Smith (red.), Encyclopedia of Global Archaeology, Springer, New York, s. 3102-3107.

Rosadziński L. (2014), Poszukiwacz, czyli niezwykli ludzie i stare książki, Rosa Dom Różności, Poznań.

Rowiński R. (1968), Poludnik 15. Reportaże, Wydawnictwo Poznańskie, Poznań, S. $5-11$.

Rybchinsky Y. (2006), Photoestafeta from Rodchenko to our days. Pages of history of Soviet and contemporary Russian photography, Moskiewski Dom Fotografii, Moskwa.

Sienkiewicz H. (2000), Listy z podróży do Ameryki, Most, Warszawa.

Straszyńska A. (2015), Strzelecka 8, „Odkrywca”, t. 11(202), s. 26-31.

Straszyńska A. (2016), Willa Jasny Dom, „Odkrywca”, t. 4(207), s. 30-35.

\section{SUMMARY}

\section{THE GHOSTS OF PLACES - INSCRIPTIONS IN THE PUBLIC AND PRIVATE SPACES AS A RESEARCH MATERIAL FOR THE ARCHAEOLOGY OF THE CONTEMPORARY PAST}

Writing, signing and carving names in public spaces are popular ways of indicating somebody's presence in the world. Various inscriptions made in different places have been appearing from the ancient times until today. There are multiple motivations for such practice: a simple signing to indicate somebody's presence, a declaration of sympathy or antipathy to some idea or person or political manifests and encouragement to engage in some actions. Despite the popularity of such phenomenon and its long duration, archaeologists, especially those involved in studying the recent or contemporary past, are not particularly focused on researching this source of knowledge. Most of the academic works which concern inscriptions and graffiti are conducted by sociologists or visual culture specialists. However, these sources may be truly significant in studying microhistories of the places and people. Thus, in our article we want to present a unique potential of graffiti in the studies related to the recent and contemporary past.

The aim of our article is to show various spatial contexts in which graffiti may be encountered and to present how the archaeology of the contemporary past may take advantage of researching such inscriptions. After Laurent Olivier (2001), we think that discovering the local past is a characteristic feature of the archaeology of the contemporary past and our article aims to show how the specific "being" of graffiti around us may contribute to discovering the microhistories of people and places. 
According to Michael Bell's concept (1997), we interpret graffiti as "the ghosts of place" which indicate the presence of those who are no longer in the place. Due to the breadth of topics connected with graffiti, we decided to focus on those inscriptions which manifest someone's presence in the place, narrowing our studies only to its written form (not graphic). 